\title{
GUCY2D Cone-Rod Dystrophy-6 Is a "Phototransduction Disease" Triggered by Abnormal Calcium Feedback on Retinal Membrane Guanylyl Cyclase 1
}

\author{
Shinya Sato, ${ }^{1}$ Igor V. Peshenko, ${ }^{2}$ Elena V. Olshevskaya, ${ }^{2}$ Vladimir J. Kefalov, ${ }^{1}$ and ${ }^{\circledR A l e x a n d e r ~ M . ~ D i z h o o r ~}{ }^{2}$ \\ ${ }^{1}$ Department of Ophthalmology and Visual Sciences, Washington University in St. Louis, St. Louis, Missouri 63110, and ${ }^{2}$ Pennsylvania College of \\ Optometry, Salus University, Elkins Park, Pennsylvania 19027
}

The Arg838Ser mutation in retinal membrane guanylyl cyclase 1 (RetGC1) has been linked to autosomal dominant cone-rod dystrophy type 6 (CORD6). It is believed that photoreceptor degeneration is caused by the altered sensitivity of RetGC1 to calcium regulation via guanylyl cyclase activating proteins (GCAPs). To determine the mechanism by which this mutation leads to degeneration, we investigated the structure and function of rod photoreceptors in two transgenic mouse lines, 362 and 379, expressing R838S RetGC1. In both lines, rod outer segments became shorter than in their nontransgenic siblings by 3- 4 weeks of age, before the eventual photoreceptor degeneration. Despite the shortening of their outer segments, the dark current of transgenic rods was 1.5-2.2-fold higher than in nontransgenic controls. Similarly, the dim flash response amplitude in $R 838 S^{+}$rods was larger, time to peak was delayed, and flash sensitivity was increased, all suggesting elevated dark-adapted free cGMP in transgenic rods. In rods expressing R838S RetGC1, dark-current noise increased and the exchange current, detected after a saturating flash, became more pronounced. These results suggest disrupted $\mathrm{Ca}^{2+}$ phototransduction feedback and abnormally high free- $\mathrm{Ca}^{2+}$ concentration in the outer segments. Notably, photoreceptor degeneration, which typically occurred after 3 months of age in R838S RetGC1 transgenic mice in $G C A P 1,2^{+/+}$or $G C A P 1,2^{+/-}$backgrounds, was prevented in $G C A P 1,2^{-/-}$mice lacking $\mathrm{Ca}^{2+}$ feedback to guanylyl cyclase. In summary, the dysregulation of guanylyl cyclase in RetGC1-linked CORD6 is a "phototransduction disease," which means it is associated with increased free-cGMP and $\mathrm{Ca}^{2+}$ levels in photoreceptors.

Key words: calcium; cGMP; guanylyl cyclase; photoreceptors; phototransduction; retinal degeneration

Significance Statement

In a mouse model expressing human membrane guanylyl cyclase 1 (RetGC1, GUCY2D), a mutation associated with early progressing congenital blindness, cone-rod dystrophy type 6 (CORD6), deregulates calcium-sensitive feedback of phototransduction to the cyclase mediated by guanylyl cyclase activating proteins (GCAPs), which are calcium-sensor proteins. The abnormal calcium sensitivity of the cyclase increases cGMP-gated dark current in the rod outer segments, reshapes rod photoresponses, and triggers photoreceptor death. This work is the first to demonstrate a direct physiological effect of GUCY2D CORD6-linked mutation on photoreceptor physiology in vivo. It also identifies the abnormal regulation of the cyclase by calcium-sensor proteins as the main trigger for the photoreceptor death.

\section{Introduction}

Retinal membrane guanylyl cyclase (RetGC), one of the essential enzymes in photoreceptor signaling, enables photosensitivity of

Received Oct. 17, 2017; revised Jan. 19, 2018; accepted Jan. 24, 2018.

Author contributions: V.J.K. and A.M.D. designed research; S.S., I.V.P., E.V.O., and A.M.D. performed research; S.S., I.V.P., V.J.K., and A.M.D. analyzed data; V.J.K. and A.M.D. wrote the paper.

This work was supported by National Institutes of Health Grants EY11522 (A.M.D.), EY19312 (V.J.K.), EY25696 (V.J.K.), EY27387 (V.J.K.), and EY02687 (Washington University, Department of Ophthalmology and Visual Sciences); a Pennsylvania Department of Health Formula Grant (A.M.D.); and by Research to Prevent Blindness. The authors declare no competing financial interests.

Correspondence should be addressed to either of the following: Alexander M. Dizhoor, Pennsylvania College of Optometry, Salus University, Elkins Park, PA 19027, E-mail: adizhoor@salus.edu; or Vladimir J. Kefalov, Department rods and cones by opening cGMP-gated channels in the outer segment plasma membrane. The partial depolarization of photoreceptors caused by the inward current of $\mathrm{Na}^{+}$and $\mathrm{Ca}^{2+}$ through cGMP-gated channels in the dark becomes reversed when light activates the hydrolysis of cGMP by phosphodiesterase 6 (PDE6) and suppresses the influx of $\mathrm{Na}^{+}$and $\mathrm{Ca}^{2+}$ (Yau and Hardie, 2009;

of Ophthalmology and Visual Sciences, Washington University in St. Louis, St. Louis, M0 63110, E-mail: kefalov@wustl.edu.

S. Sato's present address: Graduate School of Biostudies, Kyoto University, Yoshida-Konoecho, Sakyo-ku, Kyoto 606-8315, Japan.

DOI:10.1523/JNEUROSCI.2985-17.2018

Copyright $\odot 2018$ the authors $\quad 0270-6474 / 18 / 382990-11 \$ 15.00 / 0$ 

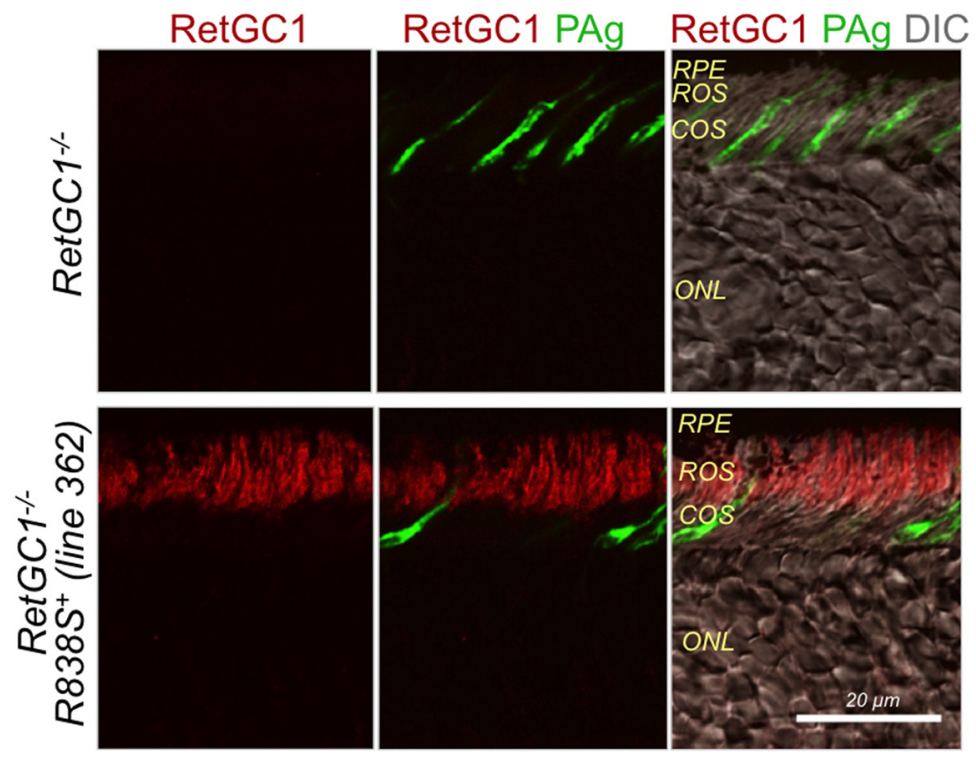

Figure 1. Rod-specific expression of R838S RetGC1 in mouse Line 362. The R838S RetGC1-expressing Line 362 (Dizhoor et al., 2016) was outcrossed to RetGC1 ${ }^{-/-}$background (Yang et al., 1999) to eliminate interference from the endogenous mouse RetGC1 immunoreactivity. Cryosections from RetGC1 ${ }^{-1-}$ (top row) and $\mathrm{R}_{838 S^{+}} \mathrm{RetGC1}^{-1-}$ (bottom row) retinas were probed by rabbit polyclonal anti-RetGC1 antibody (Laura et al., 1996) and developed using AlexaFluor 568 goat anti-rabbit (red) secondary antibody. Cone sheaths were labeled using FITC-conjugated peanut agglutinin (PAg; green). The fluorescence images were superimposed on differential interference contrast image in the rightmost panels. RPE, Retinal pigment epithelium; ROS, rod outer segments; $C O S$, cone outer segments; $0 \mathrm{NL}$, outer nuclear layer.

Arshavsky and Burns, 2012; Koch and Dell'Orco, 2015). While $\mathrm{Ca}^{2+}$ influx is suppressed upon light stimulation of rods, its extrusion via $\mathrm{Na}^{+} / \mathrm{Ca}^{2+}, \mathrm{K}^{+}$exchanger 1 (NCKX1; Reiländer et al., 1992) still carries on to produce a decrease in rod outer segment $\mathrm{Ca}^{2+}$ concentration. This upregulates the negative $\mathrm{Ca}^{2+}$ feedback on RetGC (Koch and Stryer, 1988; Pugh et al., 1999; Burns et al., 2002), which is mediated by guanylyl cyclase-activating proteins (GCAPs), which are $\mathrm{Ca}^{2+} / \mathrm{Mg}^{2+}$ sensors (Palczewski et al., 1994; Dizhoor et al., 1994, 1995, 2010; Imanishi et al., 2004; Makino et al., 2012). As a result of the light-induced decrease in $\mathrm{Ca}^{2+}$, GCAPs convert to a $\mathrm{Mg}^{2+}$-liganded state that stimulates RetGC activity. Upon the return of photoreceptors to darkness, PDE6 is inactivated, the influx of $\mathrm{Ca}^{2+}$ through the cGMP-gated channels resumes, and $\mathrm{Ca}^{2+}$ concentration returns to its dark-adapted level. Subsequently, GCAPs convert back to $\mathrm{Ca}^{2+}$-liganded state and decelerate production of cGMP.

Two isozymes of RetGC are present in photoreceptors RetGC1, the predominant isozyme in rods and cones, and RetGC2, an ancillary isozyme in rods (Dizhoor et al., 1994; Lowe et al., 1995; Yang et al., 1995; Peshenko et al., 2011; Xu et al., 2013). Multiple mutations in the human GUCY2D gene, coding for the RetGC1 isozyme, have been linked to different types of congenital blindness. Some mutations cause Leber's congenital amaurosis (LCA), which is typically a nondegenerative disease causing severe recessive blindness resulting from loss of RetGC1 activity and/or activation that renders rods and cones nonfunctional from birth (Perrault et al., 2000; Stone, 2007; Jacobson et al., 2013). Unlike GUCY2D LCA, autosomal-dominant GUCY2D cone-rod dystrophy 6 (CORD6) is an early-onset progressing degeneration of photoresponsive cones and rods, frequently linked to substitutions Cys, Ser, Pro, His, or Gly replacing Arg838 in the dimerization domain of RetGC1 (Ramamurthy et al., 2001; Ito et al., 2004; Udar et al., 2003; Hunt et al., 2010; Garcia-Hoyos et al., 2011), a part of the GCAP-regulated interface on the enzyme (Peshenko et al., 2015a,b). A number of previous in vitro studies using recombi- nant RetGC1 expressed in cultured nonphotoreceptor cells (Tucker et al., 1999; Ramamurthy et al., 2001; Peshenko et al., 2004) have shown that the Arg838 substitutions cause dysregulation of the recombinant cyclase via $\mathrm{Ca}^{2+}$ feedback in vitro such that the mutant RetGC1 complex with GCAP not only becomes activated at the low $\mathrm{Ca}^{2+}$ concentrations typical for light-adapted photoreceptors, but also retains elevated activity at $\mathrm{Ca}^{2+}$ levels typical for dark-adapted rods and cones. We recently demonstrated that mouse rods expressing R838S RetGC1 in a transgenic model rapidly degenerate, causing earlyonset progressive blindness (Dizhoor et al., 2016). We now present physiological in vivo evidence that GUCY2D CORD6 is a "phototransduction disease" triggered specifically by abnormal $\mathrm{Ca}^{2+}$ feedback to the cyclase via GCAPs.

\section{Materials and Methods}

Animals. All experiments involving animals were conducted in accordance with the US Public Health Service guidelines and approved by the Institutional Animal Care and Use Committees of Salus University and Washington University in St. Louis. Transgenic mice expressing R838S RetGC1 under control of rod opsin promoter (RRID: currently available from the Dizhoor laboratory; a request has been also submitted to JAX laboratories and assigned interim accession numbers MGI_5908882 and MGI_5908875) were produced as previously described (Dizhoor et al., 2016); GCAP1, $2^{-/-}$mouse line (Mendez et al., 2001) originally provided by Dr. Jeannie Chen and $\operatorname{Ret} G C 1^{-1-}$ mice (GC-E null, Yang et al., 1999) originated from Dr. David Garbers' laboratory were outcrossed for 10 generations to C57B6J mouse strain purchased from JAX Research (Jackson Laboratory) before breeding the knock-out alleles into a homozygous state. The $R 838 S^{+}$mouse lines were propagated by breeding Lines 362 and 379 (Dizhoor et al., 2016) to wild-type C57B6J, and the transgene-negative progeny from the breeding, both males and females, were used in the study as a littermate control.

Immunofluorescence and immunoblotting. Mice anesthetized by intraperitoneal injection of ketamine/xylazine/urethane $(80 / 32 / 800 \mathrm{mg} / \mathrm{kg}$ ) mixture were perfused through the heart with PBS, followed by $10 \%$ paraformaldehyde in PBS. The enucleated eyes were placed in $10 \%$ formaldehyde/PBS for $5 \mathrm{~min}$ at room temperature. Then the cornea and the lens were removed and the eye cup was fixed in 5\% formaldehyde/PBS for $1 \mathrm{~h}$, cryoprotected by immersing in $30 \%$ sucrose/PBS overnight at $4^{\circ} \mathrm{C}$ twice, frozen in OCT medium (Electron Microscopy Science), and sectioned using a Hacker-Bright cryomicrotome. Sections were probed with a rabbit polyclonal antibody raised against the catalytic domain of RetGC1 (Laura et al., 1996) and developed using goat anti-rabbit antibody (Invitrogen/Fisher) and fluorescein-labeled peanut agglutinin (Vector Laboratories) as described previously (Dizhoor et al., 2016). Confocal images were acquired using an Olympus FV1000 Spectral instrument controlled by FluoView FV10-ASW software, collecting in a sequential mode. No changes were made to the original images except for minor gamma correction applied to the whole image for more clear presentation in print. For Western immunoblotting, proteins extracted from the retinas with a RIPA buffer (Abcam) were mixed with equal volumes of $2 \times$ Laemmli SDS sample buffer and subjected to electrophoresis in 7\% SDS-PAAG, then transferred to PVDF membrane and probed with anti-NCKX1 or anti-CNG1 $\alpha$ mouse monoclonal antibodies (both were generously provided by Dr. Robert Molday, University of British Columbia) or anti-actin antibody (Abcam) and developed using antimouse IgG peroxidase-conjugated secondary antibody and a Femto 
A

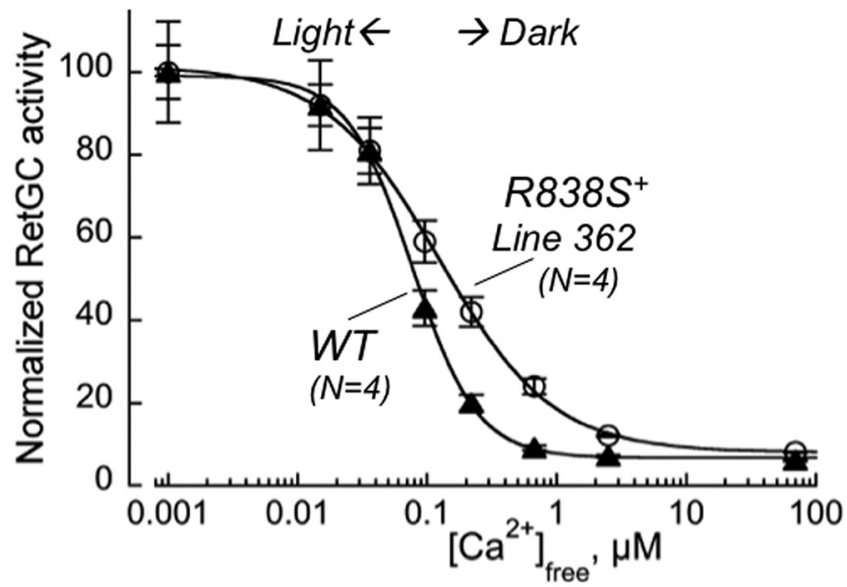

B
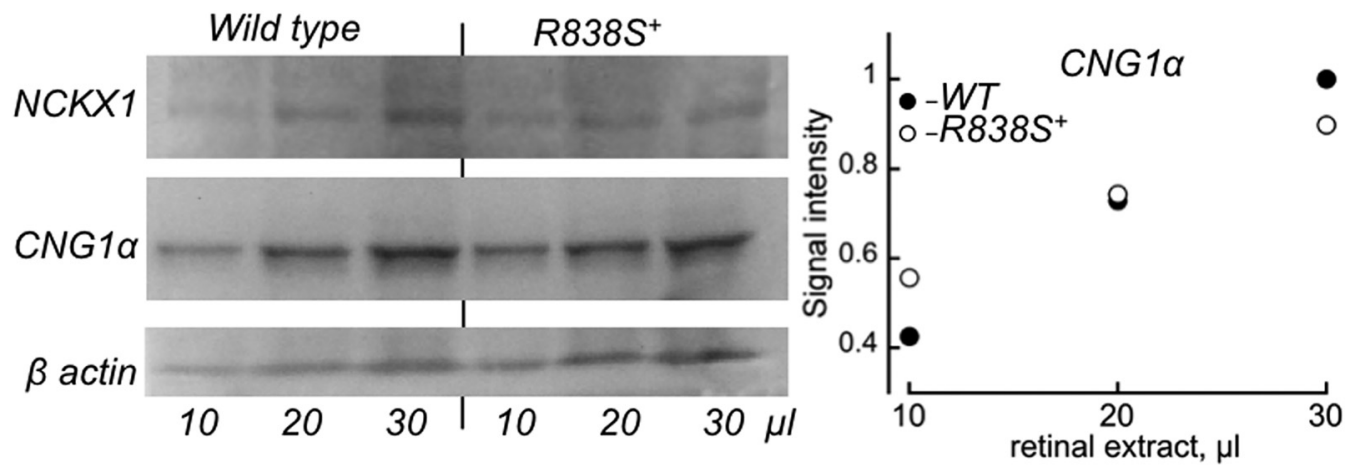

Figure 2. Expected increase in guanylyl cyclase activity in $R 838 S^{+}$rods due to the change in its $\mathrm{Ca}^{2+}$ sensitivity. $\boldsymbol{A}$, Guanylyl cyclase activity, mean \pm SD, in retinal homogenates from dark-adapted wild-type (closed triangles, $\mathbf{A}$ ) and $R 838 S^{+}$littermates (open circles, $\bigcirc$ ) was assayed as described in Materials and Methods. The activities were normalized as the percentage of maximal catalytic activity of the cyclase in each preparation and fitted with the Hill function, $A=\left(A_{\max }-A_{\min )} /\left(1+\left([\mathrm{Ca}] / K_{1 / 2 \mathrm{Ca}}\right)^{h}\right)+A_{\min }\right.$, where $A_{\max }$ and $A_{\min }$ are the respective maximal and minimal activity, $\left[\mathrm{Ca}\right.$ ] is free $\mathrm{Ca}^{2+}$ concentration, $K_{1 / 2}$ is free $\mathrm{Ca}^{2+}$ concentration causing twofold inhibition of the cyclase activity, and $h$ is the Hill coefficient. The arrows indicate the approximate range of free- $\mathrm{Ca}^{2+}$ change in mouse rods between light-adapted and dark-adapted state (Woodruff et al., 2002; Olshevskaya et al., 2004). B, Altered $\mathrm{Ca}^{2+}$ feedback on the cyclase predicted to increase CGMP production and $\mathrm{Ca}^{2+}$ influx in the dark does not upregulate CNG1 and NCKX1 expression in $R 838 S^{+}$retinas. Protein fractions extracted from R8385 ${ }^{+}$and wild-type littermates at 3 weeks of age were equalized by total protein concentration and 10,20, and $30 \mu$ l of the samples were separated using 7\% SDS-PAGE. Western immunoblot was probed with anti-NCKX1 (top), anti-CNG1 $\alpha$ (middle), and $\beta$ actin (bottom) antibodies. Chemiluminescence for CNG1 was proportional to the sample load (right) and was quantified from the immunoblot in R8385 ${ }^{+}$retinas as $1.1 \pm 0.2$ (SD), $N=3$, of the wild-type level. Signal-to-background ratio on immunoblots with NCKX1 did not allow for a reliable quantification, but the observed band intensities gave no indication of upregulation.

SuperSignal chemiluminescence substrate (Pierce/Thermo Fisher Scientific). Chemiluminescence image was acquired using a Fotodyne Luminous FX instrument.

Retinal morphology. Mice were perfused through the heart as above with PBS and then with $2.5 \%$ glutaraldehyde in PBS. The eyes were surgically removed and fixed overnight in $2.5 \%$ glutaraldehyde $/ 2.5 \%$ formaldehyde at $4^{\circ} \mathrm{C}$. The fixed eyes were washed three times for $15 \mathrm{~min}$ each in PBS, soaked in PBS overnight, processed for paraffin embedding, sectioned, and stained with hematoxylin/eosin (AML Laboratories). The outer segment length was measured from a confocal differential interference contrast image. The retina morphology was analyzed using images taken by an Olympus Magnafire camera mounted on an Olympus BX21 microscope. The photoreceptor nuclei in the outer nuclear layer of the retina were counted from a $425 \mu \mathrm{m}$ fragment of the retina, midway between the optic nerve and the periphery of the retina, and the densities of the nuclei per $100 \mu \mathrm{m}$ distance were averaged from several frames for each retina.

Guanylyl cyclase assay. Mice were dark-adapted overnight and their retinas were dissected and assayed under infrared illumination as previously described (Peshenko et al., 2011,2016). Briefly, the assay contained in $25 \mu \mathrm{l}$ of $30 \mathrm{~mm} 3$-(N-morpholino) propanesulfonic acid (MOPS)$\mathrm{KOH}$, pH 7.2, $60 \mathrm{~mm} \mathrm{KCl,} 4 \mathrm{~mm} \mathrm{NaCl}, 1 \mathrm{~mm}$ DTT, 0.3 mм ATP, 4 mм cGMP, $1 \mathrm{~mm}$ GTP, $10 \mathrm{~mm}$ creatine phosphate, 0.5 unit of creatine phosphokinase (Sigma-Aldrich), $1 \mu \mathrm{Ci}$ of $\left[\alpha^{-}{ }^{32} \mathrm{P}\right] \mathrm{GTP}, 0.1 \mu \mathrm{Ci}$ of $\left[8-{ }^{3} \mathrm{H}\right] \mathrm{cGMP}$ (PerkinElmer), phosphodiesterase inhibitors zaprinast and dipyridamole, and $2 \mathrm{mM} \mathrm{Ca}^{2+} /$ EGTA buffer, with $\mathrm{MgCl}_{2}$ added to maintain variable
$\left[\mathrm{Ca}^{2+}\right]_{\text {free }}$ at $0.9 \mathrm{~mm}$ free $\mathrm{Mg}^{2+}$ (Peshenko and Dizhoor, 2006). Where indicated, myristoylated recombinant mouse GCAP1 expressed in Escherichia coli and purified as previously described (Peshenko and Dizhoor, 2006; Peshenko et al., 2015a,b) was added to the assay.

Electrophysiology. Single-cell suction recordings were done as previously described (Wang et al., 2014). Mice were dark-adapted overnight and killed by 5 min $\mathrm{CO}_{2}$ inhalation. Then their eyes were enucleated under dim red light using forceps. Retinas were then isolated into Locke's solution (112.5 mM NaCl, $3.6 \mathrm{~mm} \mathrm{KCl}, 2.4 \mathrm{~mm} \mathrm{MgCl}, 1.2 \mathrm{~mm} \mathrm{CaCl}, 10$ mM HEPES, $20 \mathrm{~mm} \mathrm{NaHCO}, 3 \mathrm{~mm}$ sodium succinate, $0.5 \mathrm{~mm}$ sodium glutamate, $0.02 \mathrm{~mm}$ EDTA, $10 \mathrm{~mm}$ glucose, $0.1 \%$ minimum essential media vitamins, and $0.2 \%$ minimum essential media amino acids, $\mathrm{pH}$ 7.4) using microscissors and fine forceps under a stereomicroscope fit with infrared image converters. A retina was chopped by a razor blade into small pieces and transferred into the recording chamber perfused with $33-37^{\circ} \mathrm{C}$ Locke's solution equilibrated with $95 \% \mathrm{O}_{2} / 5 \% \mathrm{CO}_{2}$. A single rod outer segment was then drawn into a microglass pipette under microscope (IX51, Olympus) with infrared illumination and camera. The pipette was filled with electrode solution $(140 \mathrm{~mm} \mathrm{NaCl}, 3.6 \mathrm{~mm} \mathrm{KCl}$, $2.4 \mathrm{~mm} \mathrm{MgCl}_{2}, 1.2 \mathrm{~mm} \mathrm{CaCl}_{2}, 3 \mathrm{~mm}$ HEPES, $0.02 \mathrm{~mm}$ EDTA, $10 \mathrm{~mm}$ glucose, $\mathrm{pH} 7.4$ with $\mathrm{NaOH}$ ) and controlled by micromanipulator (MP225 , Sutter Instrument). Test flashes of 500 or $505 \mathrm{~nm}$ were generated in a calibrated LED light stimulus system and delivered to the recording chamber through a custom-made optical system. Flash intensity and duration were controlled by an LED driver (LDC210, Thorlabs) con- 

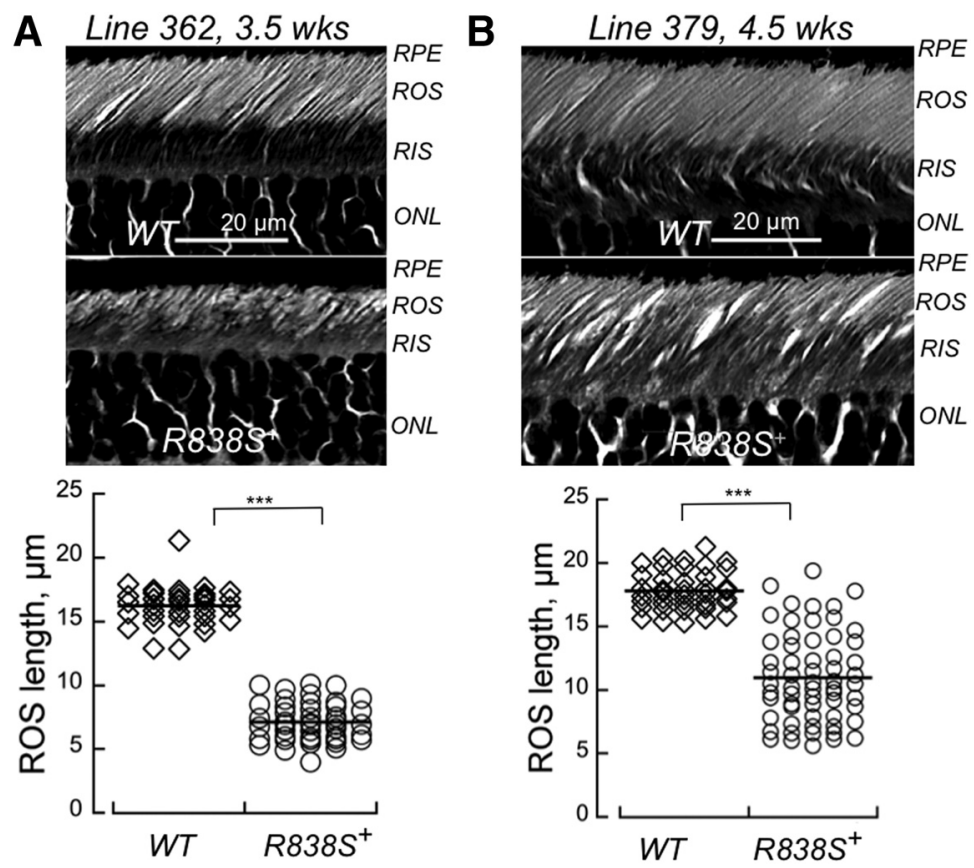

Figure 3. Shortening of the outer segment in $R 838 S^{+}$rods occurs at early ages in Lines $362(\boldsymbol{A})$ and $379(\boldsymbol{B})$. Top, Differential interference contrast images of sections from wild-type and $R 838 S^{+}$littermates perfused and fixed with glutaraldehyde/paraformaldehyde solution at 3.5 and 4.5 weeks, respectively. Bottom, Length distribution for the outer segments of wild-type and identifiable $R 838 \mathrm{~S}^{+}$rods. The horizontal bars represent the mean average for each group. RPE, Retinal pigment epithelium; ROS, rod outer segments; RIS, rod inner segments; $0 \mathrm{NL}$, outer nuclear layer; ${ }^{* * *} p<0.0001, t$-test.

A

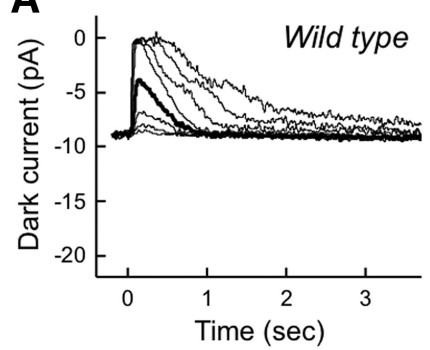

C

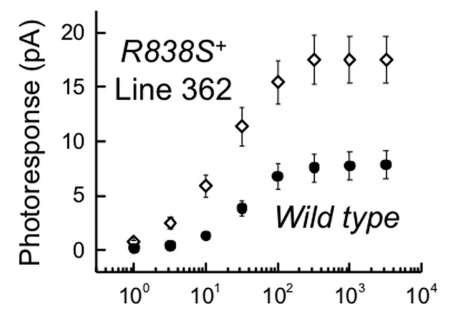

Flash strength (photons $\cdot \mu \mathrm{m}^{-2}$ )

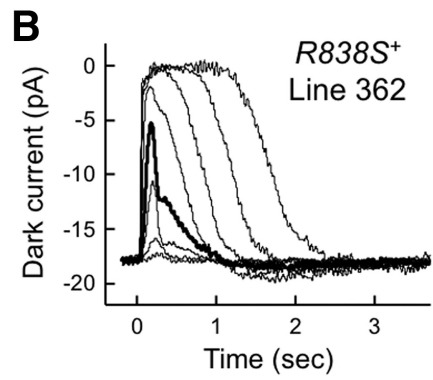

D

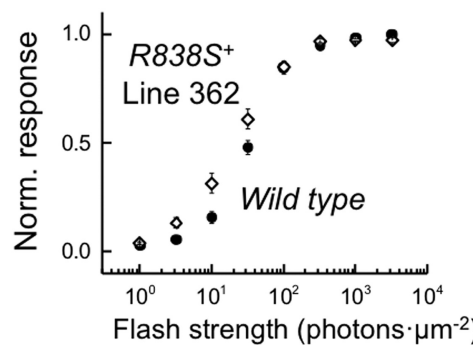

Figure 4. Increased dark current in Line $362 R 838 S^{+}$rods. $A, B$, Representative response families to flash stimuli recorded by suction electrode from a wild-type $(\boldsymbol{A})$ and Line $362 \mathrm{R} 38 \mathrm{~S}^{+}$rods $(\boldsymbol{B})$. Data were obtained at $4-4.5$ weeks of age. Flash strength ranged from 1 to 3200 photons $\cdot \mu \mathrm{m}^{-2}$ with $0.5 \log$ unit steps and flash duration was 2 or $20 \mathrm{~ms}$. Bold traces represent the responses of the two rods to a flash of 32 photons $\cdot \mu \mathrm{m}^{-2}$. C, $D$, Intensity-response curves of wild-type (filled circles, $O$ ) and Line $362{\mathrm{R} 838 S^{+}}^{+}$(open diamonds, $\diamond$ ) rods shown in absolute $(\boldsymbol{C}$ ) or normalized $(\boldsymbol{D})$ values. Data are shown as mean $\pm \mathrm{SEM}, N=6$ (wild type) and $16\left(\right.$ R838S $\left.^{+}\right)$. Data in $\boldsymbol{D}$ were also fitted with the Naka-Rushton equation (the fitting curves are not shown in the panel), $r=I^{n} /\left(I^{n}+I_{0}^{n}\right)$, where $r$ is a normalized photoresponse amplitude, I is flash intensity, $I_{0}$ is half-saturating flash intensity, and $n$ is a constant that controls the slope; there was no significant difference in slope between the wild-type $(n=1.42 \pm 0.06)$ and the $R 838 S^{+}$rods $(1.25 \pm 0.06)$; $P$ value for two-tailed unpaired test was 0.15 .

nected to a computer and operated by pClamp9 software (Molecular Devices). Signals from individual rods were amplified by an amplifier (Axopatch 200B, Molecular Devices) and a tunable active filter (model 3382, Krohn-Hite), low-pass filtered at $30 \mathrm{~Hz}$ (8-pole Bessel, model 3382,
Krohn-Hite), digitized at $1 \mathrm{kHz}$ (Digidata 1322A, Molecular Devices), stored and analyzed on a computer using pClamp9.

Experimental design and statistical analysis. All animal experiments indiscriminately used male and female mice. Since the magnitude of the expected effects, by the nature of the experiments, was not feasible to predict a priori, the size of the animal groups was not explicitly planned in advance and the statistical analysis was applied to the data collected upon the completion of the experiments. Unless noted otherwise, two-tailed unpaired Student's $t$ test (Origin8, OriginLab) was used to test for the significance of differences in the mean values of two sample groups. $P$ values of $<0.05$ were considered to be statistically significant. Where indicated, one-way ANOVA/Bonferroni test at $\alpha=0.01$ (KaleidaGraph, Synergy Software) was applied for comparison of photoreceptor loss between several animal groups.

\section{Results}

\section{The R838S RetGC1 expression} dysregulates cyclase modulation by $\mathrm{Ca}^{2+}$

Two mouse lines expressing the R838S RetGC1 under control of rod opsin promoter, Lines 362 and 379, have been shown to undergo rapid early-onset loss of rod electroretinography (ERG) concomitant with the degeneration of rods. This degeneration is more severe in Line 362 (Dizhoor et al., 2016). To determine whether the R838S RetGC1 transgene in the fast-degenerating line 362 is expressed in rod photoreceptor outer segments, the line was outcrossed to Ret $G C 1^{-/-}$background, which eliminates interference from the endogenous mouse RetGC1 ortholog (Yang et al., 1999). Immunolabeling of retinal sections demonstrated the robust and uniform expression of RetGC in rod outer segments of $\mathrm{R}_{838 S^{+}}$RetGC1 $^{-/-}$mice (Fig. 1). Thus, R838S RetGC1 was specifically expressed in Line 362 transgenic rods. This result, together with the previous finding that the mutant cyclase is expressed in the rods of Line 379 (Dizhoor et al., 2016), enabled investigation of the function of individual rods expressing R838S RetGC1 in the two transgenic lines. The experiments described further were conducted using the original $R 838 S^{+}$mouse lines, propagated in RetGC1 ${ }^{+/+}$background.

The guanylyl cyclase activity measured in the retina using our standard assay (Peshenko et al., 2011) directly assesses $\mathrm{Ca}^{2+}$ sensitivity of the photoreceptorspecific RetGC activity (Olshevskaya et al., 2004, 2012; Woodruff et al., 2007; Makino et al., 2008, 2012). Despite the fast degeneration of $R 838 S^{+}$rods in Line 362 (Dizhoor et al., 2016), their cyclase activity was still measurable at 3 weeks of age, allowing for a comparison of RetGC $\mathrm{Ca}^{2+}$ sensitivity between transgene- 
positive and transgene-negative littermates (Fig. 2A). The CORD6-linked R838S mutation in RetGC1 has a dual effect on the cyclase regulatory properties in the retina. It increases $\mathrm{EC}_{50}$ values for the inhibitory effect of $\mathrm{Ca}^{2+}$ (from $76 \mathrm{~nm}$ in wild-type littermates to $123 \mathrm{~nm}$ in the transgenepositive mice of Line 362) and causes nearly twofold reduction of the Hill coefficient (from 1.73 to 0.99 ). As a result, the cyclase activity remained markedly elevated at the free- $\mathrm{Ca}^{2+}$ concentrations typical for the normal dark-adapted mouse photoreceptors (Olshevskaya et al., 2004; Woodruff et al., 2007; Fig. 2A). We hence reasoned that if the altered $\mathrm{Ca}^{2+}$ sensitivity of the cyclase measured in retinal homogenate in vitro translates into a corresponding increase of free cGMP in living $R_{838 S^{+}}$rods, then one would expect a larger fraction of the channels to remain open in dark-adapted $R 838 S^{+}$rods, producing a larger inward dark current. To adequately interpret any potential changes in the dark current, we also verified that dysregulation of the cyclase does not result in a compensatory upregulation of the CNG1 channel in the transgenic retinas (Fig. $2 B$ ).

\section{The presence of a CORD6 RetGC1 in rods elevates their dark current and delays their response kinetics}

The outer segment of degenerating $R 838 S^{+}$ rods were still present at a young age for both Lines 362 and 379, despite showing nearly twofold and 1.5-fold reduction in length at 3.5 weeks of age (Fig. $3 A$ ) and 4.5 weeks of age (Fig. $3 B$ ) respectively, which preceded their pronounced degeneration at later stages (Dizhoor et al., 2016; see Fig. 9). This made possible the functional analysis of $R 838 S^{+}$rods before their degeneration by recordings with a suction pipette electrode (Figs. 4-8; Tables 1, 2). Notably, despite the reduction of their outer segment length, $R_{838 S^{+}}$rods from both mouse lines exhibited significantly elevated dark current compared with their respective nontransgenic littermates. The increase in dark current was twofold in Line 362 (Fig. 4; Table 1) and 1.5-fold in Line 379 (Fig. 5; Table 2) at 4 weeks of age. Taking into account the reduced length of the outer segment (Fig. 3), such increase in the dark current indicates an even more drastic increase in the cGMP-gated current density in $R 838 S^{+}$rods. This result is consistent with the inefficient suppression of the RetGC1 activity at dark-adapted $\mathrm{Ca}^{2+}$ levels in $\mathrm{R}^{2} 38 S^{+}$rods (Fig. 2). The larger fraction of open cGMP-gated channels in the dark and the slower activation
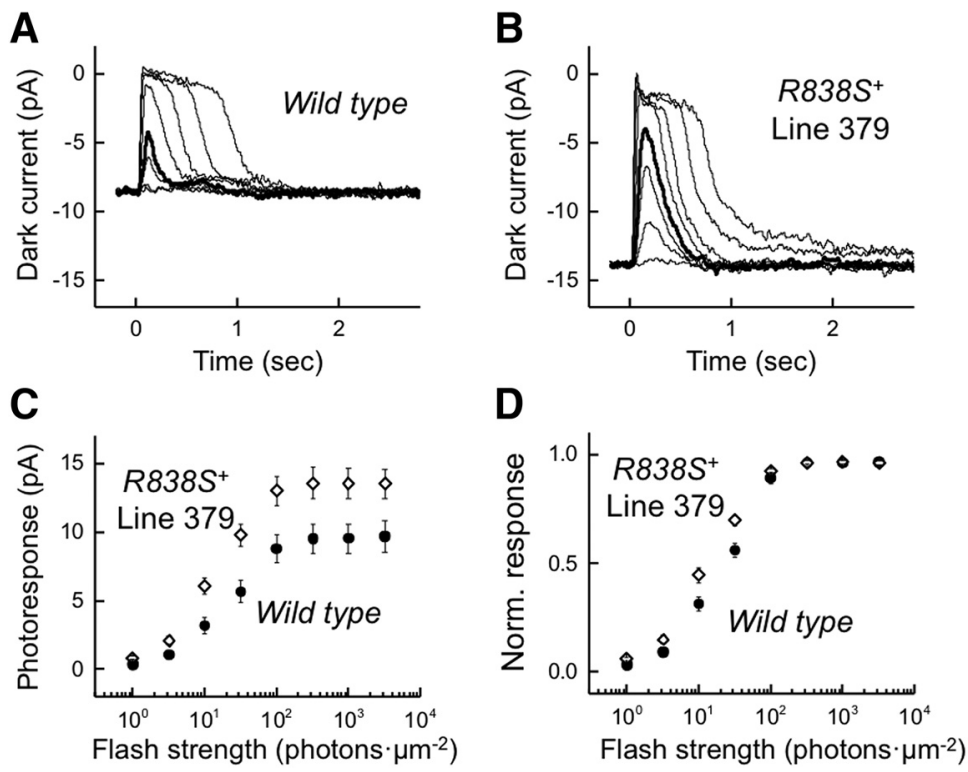

Figure 5. Increased dark current in Line 379 R838S $^{+}$rods. $\boldsymbol{A}, \boldsymbol{B}$, Representative response families to flash stimuli recorded by suction electrode from a wild-type $(\boldsymbol{A})$ and Line $379 R 838 S^{+}$rods $(\boldsymbol{B})$. Data were obtained at $4-4.5$ weeks of age. Flash strength ranged from 1 to 3200 photons $\cdot \mu \mathrm{m}^{-2}$ with $0.5 \mathrm{log}$ unit steps and flash duration was 2 or $20 \mathrm{~ms}$. Bold traces represent the responses of the two rods to a flash of 32 photons $\cdot \mu \mathrm{m}^{-2}$. C, D, Intensity-response curves of wild-type (filled circles, $O$ ) and Line $379 R^{2} 838 S^{+}$(open diamonds, $\diamond$ ) rods shown in absolute $(\boldsymbol{C}$ ) or normalized $(\boldsymbol{D})$ values. Data are shown as mean \pm SEM, $N=11$ (wild type) and $24\left(R 838 S^{+}\right)$. In $\boldsymbol{D}$, the slope parameter $n$ from the Naka-Rushton equation (fitting curves not shown) was not significantly different between wild type $(1.20 \pm 0.07)$ and $R 838 S^{+}(1.23 \pm$ $0.04) ; P$ value for two-tailed unpaired test was 0.74 .
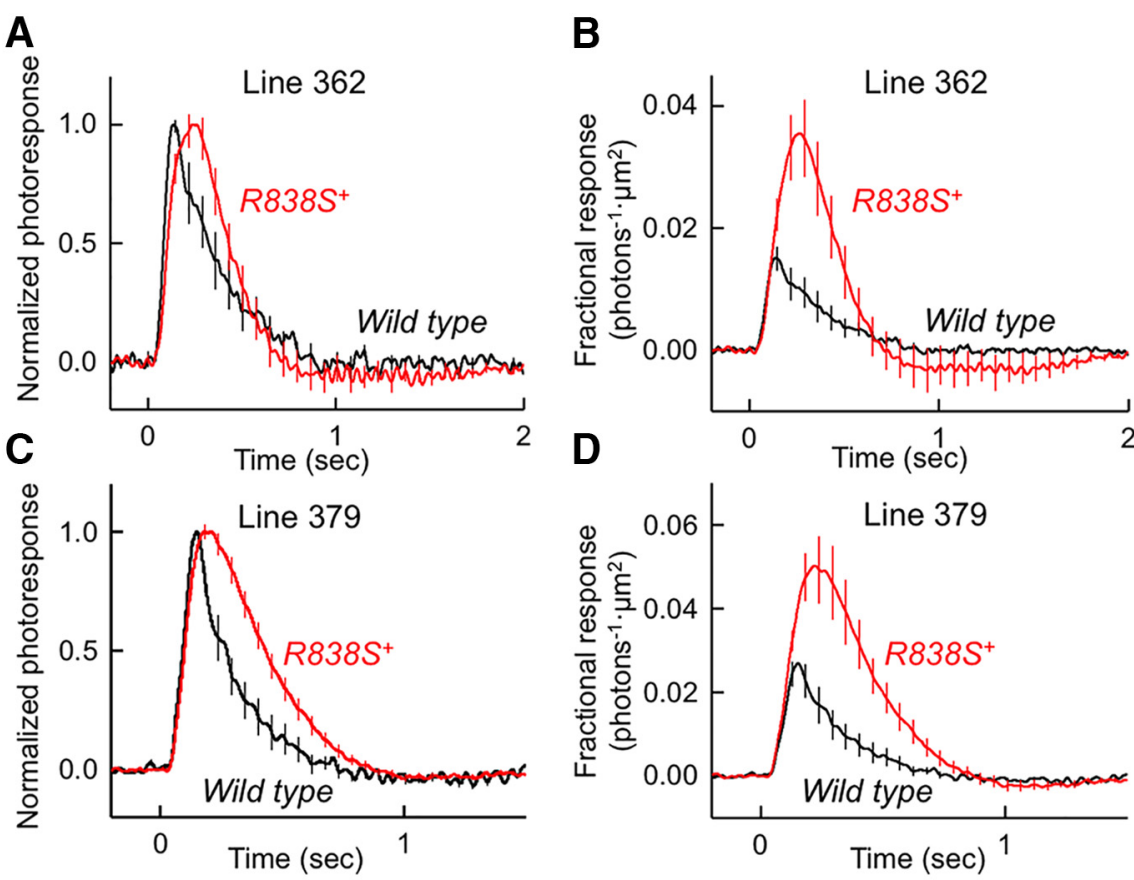

Figure 6. Delayed onset of dim flash response recovery in $R 838 S^{+}$rods. $\boldsymbol{A}-\boldsymbol{D}$, Averaged normalized $(\boldsymbol{A}, \boldsymbol{C})$ and fractional $(\boldsymbol{B}, \boldsymbol{D})$ $\operatorname{dim}$ flash responses from wild-type (black traces) and $R 8385^{+}$(red traces) rods from Line $362(\boldsymbol{A}, \boldsymbol{B})$ and Line $379(\boldsymbol{C}, \boldsymbol{D})$ mice. Fractional responses (photons ${ }^{-1} \cdot \mu \mathrm{m}^{2}$ ) were obtained by dividing dim flash responses $(\mathrm{pA})$ by dark current $(\mathrm{pA})$ and flash intensity (photons $\cdot \mu \mathrm{m}^{-2}$ ). Flash strength in $\boldsymbol{A}$ and $\boldsymbol{B}$ were 10 photons $\cdot \mu \mathrm{m}^{-2}$ for wild type and 3 or 10 photons $\cdot \mu \mathrm{m}^{-2}$ for $R 838 S^{+}$. Flash strength in $C$ and $\boldsymbol{D}$ were 3 or 10 photons $\cdot \mu \mathrm{m}^{-2}$ for wild type and 1,3, or 10 photons $\cdot \mu \mathrm{m}^{-2}$ for $R 838 S^{+}$, all with a flash duration of 2 or $20 \mathrm{~ms}$. The specific flash intensity was selected depending on the sensitivity of each rod. Data are shown as mean \pm SEM, $N=6$ (wild type in Line 362 panel), 17 (R838S ${ }^{+}$Line 362$), 11$ (wild type in Line 379 panel), and 24 (R838S $^{+}$Line 379). 

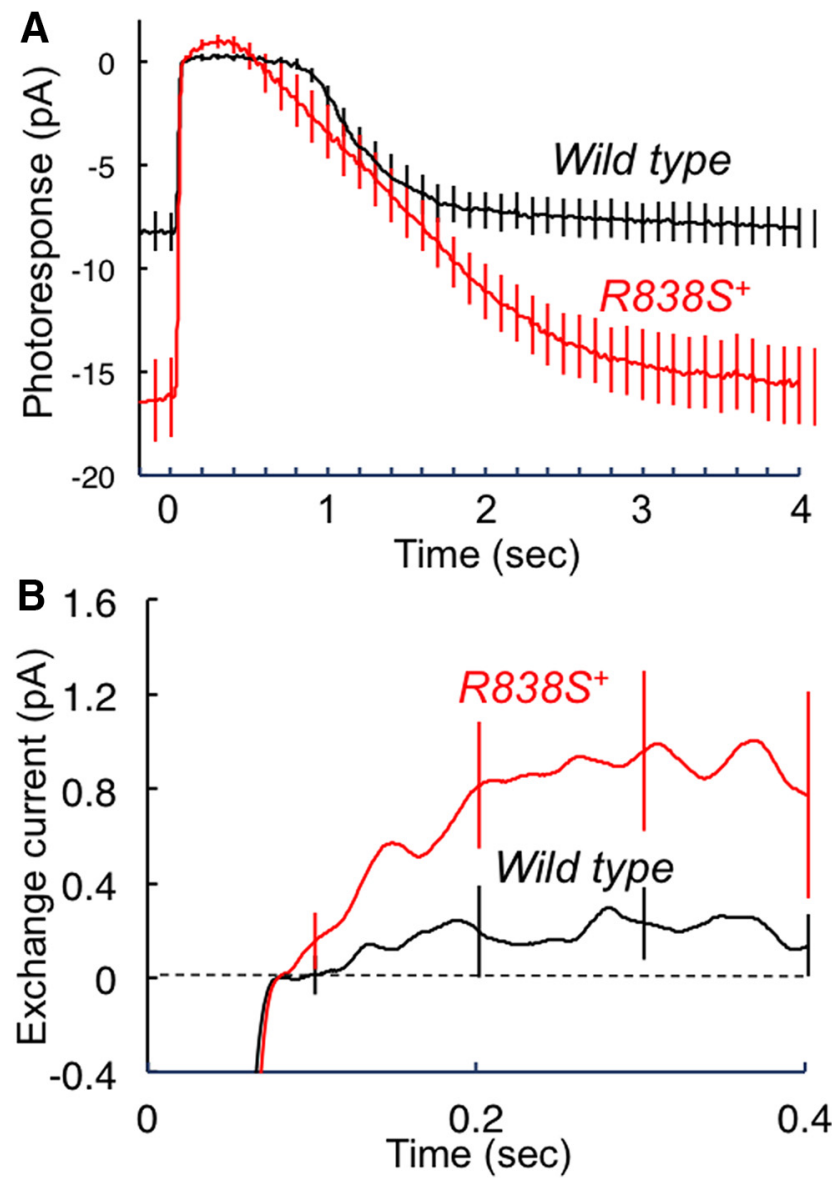

Figure 7. Increased NCKX1 exchange current in $R 8385^{+}$rods. $A$, Averaged saturating flash responses of wild-type (black) and $R 8385^{+}$(red) rods from Line 362 . Each trace was set to $0 \mathrm{pA}$ at $0.08 \mathrm{~s}$ after the 3200 photons $\cdot \mu \mathrm{m}^{-2}$ flash stimulus when the cGMP-gated current becomes fully blocked. $\boldsymbol{B}$, Magnified view of the peaks of the responses from $\boldsymbol{A}$. Data are shown as mean $\pm \mathrm{SEM}, N=10$ (wild type) and $16\left(R_{838 S^{+}}\right)$.

of RetGC due to reduced cooperativity for $\mathrm{Ca}^{2+}$ (Fig. 2A) can explain the increased flash sensitivity of mutant rods, such that a larger response amplitude was produced by a given flash in Lines 362 and 379 in comparison with their respective wild-type littermates (Fig. 4C; Table 1; Fig. 5C; Table 2, respectively). The halfsaturation flash strength, $I_{1 / 2}$, which is independent of the size of the dark current, was less affected in the mutant rods than their dim flash sensitivity (Figs. 4D, 5D; Tables 1, 2).

Unexpectedly, some of the parameters for the wild-type animals differed slightly between Tables 1 and 2. These differences are likely attributable to differences in the genetic background of the wild-type animals used as controls in each case (derived from independent crosses of $R 838 S^{+}$mice of each transgenic line with C57B6J), slight variability in age, and possibly stress from the shipment of the animals from Pennsylvania to Missouri the day before the recordings. However, as in each case we used littermates as controls, the control wild-type animals had the same genetic background, were of the same age, and were shipped together with their respective $R 838 S^{+}$siblings. As a result, the differences between wild-type and $R 838 S^{+}$transgenic rods in each case would be independent of other factors and reflect the change in rod function caused by the expression of R838S RetGC.

The shape of dim flash responses in $R 838 S^{+}$rods also changed in a manner consistent with elevated free-cGMP content: the amplitude of the flash response rose and reached its peak later in both Line 362 (Fig. 6A,B) and Line 379 (Fig. 6C,D). However, the rod dim flash recovery time constant, dominated by the inactivation of transducin (Krispel et al., 2006), was not significantly different between transgenic and wild-type littermate controls (Fig. 6; Tables 1, 2), indicating normal transducin/PDE6 complex inactivation. Similarly, the rising phase of the fractional response was unaffected by the expression of R838S RetGC1 in both Line 362 (Fig. 6B) and Line 379 (Fig. 6D). Thus, the activation of the phototransduction cascade remained unaltered in the mutant rods.

The current carried through the NCKX1 exchanger can be observed following the rapid closing of all cGMP-gated channels by a saturating flash (Yau and Nakatani, 1984). Notably, this exchange current was more pronounced in $R 838 S^{+}$rods than in wild-type littermates (Fig. 7A). Direct comparison of the exchange currents, measured from the point of saturation of the cGMP-gated channels revealed that it is $\sim 3$-fold larger in $R 838 S^{+}$ rods compared with rods of wild-type controls (Fig. $7 B$ ). We found no indications of the NCKX1 content being upregulated in $R_{838 S^{+}}$rods by Western immunoblotting (Fig. $2 B$ ). Therefore, the more pronounced exchange current in $R 838 S^{+}$rods is consistent with their larger dark current and argues that the free$\mathrm{Ca}^{2+}$ concentration in their outer segments becomes elevated.

\section{The presence of a CORD6 RetGC1 in rods increases their dark noise}

During the recordings from $R 838 S^{+}$rods, we noticed that the baseline of the recordings in darkness had frequent "bumps." Such increase in dark noise was observed in rods from both Lines 362 and 379 but not in control wild-type rods (Fig. $8 A, B$ ). This observation is reminiscent of the increased dark noise in $G C A P^{-/-}$ mouse rods (Burns et al., 2002). In that case, the lack of proper phototransduction feedback and slow $\mathrm{Ca}^{2+}$-mediated inactivation renders the discrete events caused by spontaneous activation of visual pigment 4-5 times larger than normal, making them readily observable in the dark. To test whether the increased dark noise in $\mathrm{R}_{838 S^{+}}$rods was caused by abnormal Ca ${ }^{2+}$-mediated feedback on rod phototransduction, we first evaluated the instrumental noise in $R 838 S^{+}$rods under saturating background light. In this condition, the cGMP-gated channels are closed so that phototransduction signals, including those from the spontaneous activation of the pigment, become undetectable. Notably, the discrete bumps were not observed in bright-light recordings (Fig. $8 A, B$, bottom traces), indicating that they were not derived from the instrumental noise, but rather were generated by rod phototransduction. We next analyzed the power spectrum of the dark noise (Fig. $8 C, D)$. Its phototransduction component was extracted by subtracting the instrumental (bright light) spectrum from the total darknoise spectrum. The difference spectra thus obtained were well fitted with the scaled power spectrum of the averaged dim flash response for both Line 362 (Fig. 8E) and Line 379 (Fig. 8F), demonstrating that the origin of the discrete dark noise in $R 838 S^{+}$rods is the spontaneous activation of visual pigments. Thus, similar to the case in $G C A P^{-/-}$rods (Burns et al., 2002), the abnormal $\mathrm{Ca}^{2+}$-mediated feedback on the cyclase resulted in increased dark noise in both lines expressing the mutant R838S RetGC.

\section{$\mathrm{R838S}^{+}$rod degeneration is triggered by dysregulation of the} $\mathrm{Ca}^{2+}$ feedback via GCAPs

Mouse photoreceptors express only two homologs of GCAPsGCAP1 and GCAP2 (Howes et al., 1998). To test whether the abnormal regulation of the RetGC1 harboring CORD6 mutation was the main event triggering the downstream processes eventu- 
A

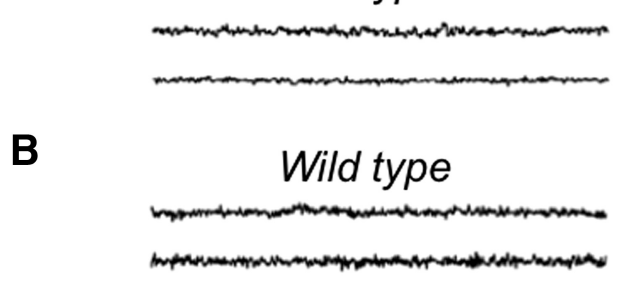

Line 362

Dark Instrumental

Line 379

Dark Instrumental

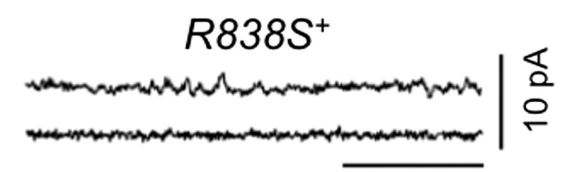

E

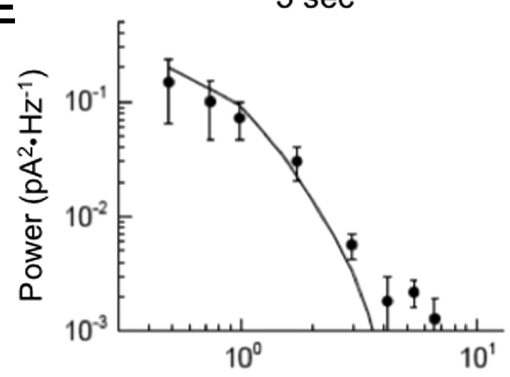

F

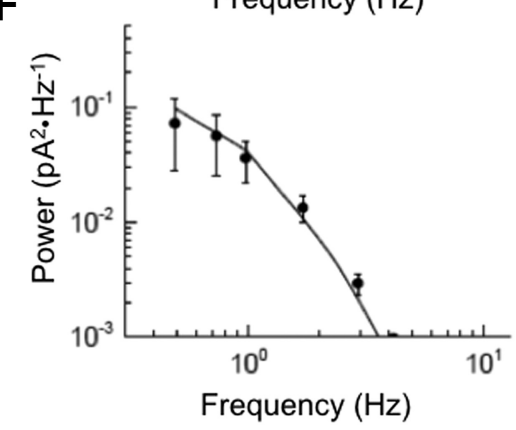

Figure 8. Increased dark noise in $R 838 S^{+}$rods. $\boldsymbol{A}, \boldsymbol{B}$, Representative traces demonstrating noise in darkness (Dark) and in bright light (Instrumental) recorded from wild-type (left) and $R 838 S^{+}$ (right) rods of Line $362(\boldsymbol{A})$ or Line $379(\boldsymbol{B})$ mice. Data were low-pass filtered at $10 \mathrm{~Hz}$. C, D, Power spectra of dark noise (Dark, filled circles, $\mathbf{O})$ and instrumental noise (Instrument, open circles, $\bigcirc$ ) from wild-type (left) and $R 838 S^{+}$(right) rods of Line 362 (C) or Line $379(\boldsymbol{D})$ mice. Data are shown as mean \pm SEM. N values are shown in the labels. $\boldsymbol{E}$, $\boldsymbol{F}$, Phototransduction component of the noise power spectrum of $R 838 S^{+}$rods (filled circles, $O$ ), fitted with a scaled power spectrum of dim flash responses. Plots were obtained by subtracting instrumental power spectrum from dark-noise power spectrum. Curves were fitted with least-square method. Data are shown as mean \pm SEM.

Table 1. Parameters of single-cell suction recordings for $R 838 S^{+}$rods from Line 362

\begin{tabular}{|c|c|c|c|}
\hline Parameter & Wild type & $R_{838 S^{+}}$ & $P$ value $^{a}$ \\
\hline Dark current (pA) & $7.9 \pm 1.3$ & $19 \pm 2$ & $0.014^{b}$ \\
\hline Exchange current $(\mathrm{pA})^{c}$ & Not available & $1.2 \pm 0.3$ & - \\
\hline Flash sensitivity $\left(\mathrm{pA} \cdot\right.$ photons $\left.^{-1} \cdot \mu \mathrm{m}^{2}\right)$ & $0.13 \pm 0.03$ & $0.77 \pm 0.15$ & $0.021^{b}$ \\
\hline Fractional sensitivity (photons ${ }^{-1} \cdot \mu \mathrm{m}^{2}$ ) & $0.016 \pm 0.002$ & $0.039 \pm 0.006$ & $0.033^{b}$ \\
\hline Time to peak (ms) & $142 \pm 7$ & $232 \pm 15$ & $0.003^{b}$ \\
\hline Recovery time constant (ms) & $180 \pm 27$ & $219 \pm 33$ & 0.503 \\
\hline Integration time (ms) & $281 \pm 48$ & $329 \pm 37$ & 0.494 \\
\hline Half-saturation flash sensitivity (photons $\cdot \mu \mathrm{m}^{-2}$ ) & $34 \pm 3$ & $24 \pm 4$ & 0.129 \\
\hline Number of cells & 6 & 17 & - \\
\hline
\end{tabular}

${ }^{a}$ Two-tailed unpaired $t$ test.

${ }^{b}$ Statistically significant differences.

'Observed in 1 of 6 wild-type rods and in 10 of $17 R 838 S^{+}$rods.

ally leading to the photoreceptor death, we compared the rate at which $R 838 S^{+}$rods degenerated in mice having normal $\left(G C A P 1,2^{+/+}\right)$ or partially reduced $\left(G C A P 1,2^{+/-}\right)$content of GCAPs versus mice completely lacking both GCAPs (GCAP1,2 $2^{-/-}$; Mendez et al., 2001). The respective genotypes were bred by repetitively crossing Line 362 to the GCAP1,2 $2^{-1-}$ double knock-out mice. In contrast to the normal $\left(G C A P 1,2^{+/+}\right)$and hemizygous $\left(G C A P 1,2^{+/-}\right)$backgrounds, a complete lack of GCAPs to medi-
Table 2. Parameters of single-cell suction recordings for $R 838 S^{+}$rods from Line 379

\begin{tabular}{|c|c|c|c|}
\hline Parameter & Wild type & $R_{838 S^{+}}$ & $P$ value ${ }^{a}$ \\
\hline Dark current (pA) & $9.9 \pm 1.1$ & $14.1 \pm 1.1$ & $0.031^{b}$ \\
\hline Flash sensitivity $\left(\mathrm{pA} \cdot\right.$ photons $\left.^{-1} \cdot \mu \mathrm{m}^{2}\right)$ & $0.29 \pm 0.06$ & $0.80 \pm 0.14$ & $0.023^{b}$ \\
\hline Fractional sensitivity (photons ${ }^{-1} \cdot \mu \mathrm{m}^{2}$ ) & $0.028 \pm 0.003$ & $0.056 \pm 0.009$ & $0.037^{b}$ \\
\hline Time to peak (ms) & $150 \pm 6$ & $198 \pm 9$ & $0.02^{b}$ \\
\hline Recovery time constant (ms) & $182 \pm 24$ & $188 \pm 15$ & 0.824 \\
\hline Integration time (ms) & $215 \pm 25$ & $321 \pm 19$ & $0.02^{b}$ \\
\hline Half-saturation flash sensitivity (photons $\cdot \mu \mathrm{m}^{-2}$ ) & $24 \pm 3$ & $15 \pm 2$ & $0.005^{b}$ \\
\hline Number of cells & 11 & 24 & - \\
\hline
\end{tabular}

${ }^{a}$ Two-tailed unpaired $t$ test.

${ }^{b}$ Statistically significant differences.

ate $\mathrm{Ca}^{2+}$ feedback on the CORD6 cyclase preserved normal retinal morphology in $R_{838 S^{+}}$mice (Fig. $9 A, B$ ). Even after 5 months, when the photoreceptor layer in Line 362 was obliterated, the histology of $R 838 S^{+} G C A P 1,2^{-/-}$retinas remained indistinguishable from that of wild type (Fig. 9A). While the Line

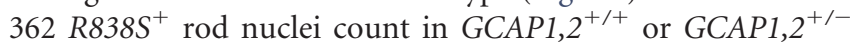
mice fell by $>80 \%$ after 3 months of age, the thickness of the outer nuclear layer in $\mathrm{R} 38 \mathrm{~S}^{+} \mathrm{GCAP} 1,2^{-1-}$ retinas did not differ from wild-type controls and remained normal even after 6 months (Fig. 9B, C). 

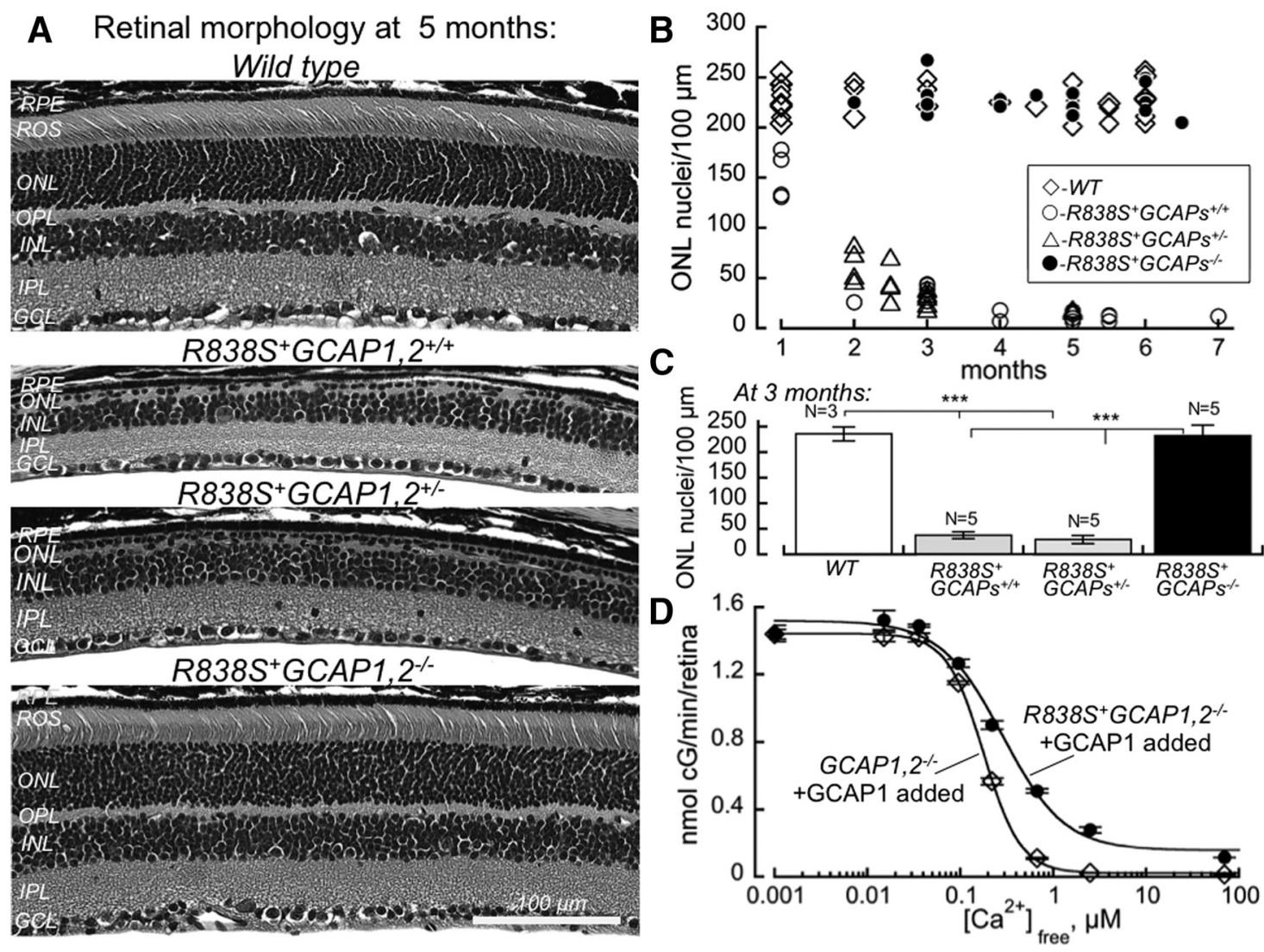

Figure 9. Retinal degeneration in $R 838 \mathrm{~S}^{+}$mice is triggered by abnormal $\mathrm{Ca}^{2+}$ feedback on R838S RetGC1 via GCAPs. $A$, Representative microphotographs of retinal histology at 5 months of age. Top to bottom, Wild-type, $R 838 \mathrm{~S}^{+} \mathrm{GCAP1}, 2^{+/+}, \mathrm{R}_{38} 8 \mathrm{~S}^{+} \mathrm{GCAP1}, 2^{+/-}$, and $R 838 \mathrm{~S}^{+} \mathrm{GCAP1}, 2^{-/-}$mice. The retinas from aldehyde-perfused mice were embedded and cross-sectioned as described in Materials and Methods. RPE, Retinal pigment epithelium; ROS, rod outer segments; ONL, outer nuclear layer; OPL, outer plexiform layer; INL, inner nuclear layer; IPL, inner plexiform layer; GCL, ganglion cell layer. Scale bar, $100 \mu \mathrm{m}$. B, Photoreceptor degeneration in wild-type (open diamonds, $\diamond), R 838 S^{+} G C A P 1,2^{+/+}$(open circles, $O$ ), $R 838 S^{+}$GCAP1, $^{+/-}$(open triangles, $\triangle$ ), and $R 8385^{+} \mathrm{GCAP1}_{1} 2^{-/-}$(closed circles, $)$mice. The $0 \mathrm{NL}$ nuclei count per $100 \mu \mathrm{m}$ retina section length between the optic nerve and the periphery of the retina was sampled at different ages. Each data point represents a single animal. $C$, The reduction of ONL thickness at 3 months of age in wild-type, $R 8385^{+} G C A P 1,2^{+/+}, R_{8385}{ }^{+} G C A P 1,2^{+/-}$, and $R 838 S^{+}{ }^{-} C A P 1,2^{-/-}$mice was tested by one-way ANOVA with a post hoc Bonferroni all-pairs comparison $(\alpha=0.01)$ using Synergy Kaleidagraph software; ${ }^{* * *} p<0.0001$; no difference was found in wild type versus $R 8385^{+} \mathrm{GCAP1}_{1} 2^{-1-} . \mathrm{D}, \operatorname{In} R 838 \mathrm{~S}^{+} \mathrm{GCAP1}, 2^{-\prime-}$, the R838S RetGC1 activity, masked by the lack of GCAPs, retains the propensity for abnormal Ca ${ }^{2+}$ sensitivity. Guanylyl cyclase activity, mean \pm $\mathrm{SD}$, in dark-adapted $\mathrm{GCAP1}, 2^{-\prime-}$ (open diamonds, $\left.\diamond\right)$ and $R 838 S^{+} \mathrm{GCAP1}, 2^{-\prime-}$ (closed circles, $\bigcirc$ ) mouse retinal homogenates was assayed as described in Figure $2 A$, except that the assay was supplemented with $5 \mu \mathrm{m}$ purified recombinant mouse GCAP1 to enable activation and $\mathrm{Ca}^{2+}$ sensitivity of the endogenous RetGC. The data were fitted with the Hill function.

To further verify that the CORD6 cyclase mutant expressed in the $R 838 S^{+} G C A P 1,2^{+/-}$rods still retained its propensity for abnormal regulation by GCAPs, we compared the $\mathrm{Ca}^{2+}$ sensitivity of the cyclase in GCAP1, $2^{-1-}$ mice harboring normal complement of RetGC1 and RetGC2 (Mendez et al., 2001; Peshenko et al., 2011) and in $R 838 S^{+} G C A P 1,2^{-/-}$mice, by reconstituting the homogenates of their dark-adapted retinas with purified recombinant mouse GCAP1. The $\mathrm{Ca}^{2+}$ sensitivity of the cyclase in $R 838 S^{+} G C A P 1,2^{-/-}$retinas in the presence of the added GCAP1 was shifted toward higher $\mathrm{Ca}^{2+}$ concentrations in a manner similar to the original Line 362 (Fig. 9D). We also bred four $R 838 S^{+} G C A P 1,2^{-/-}$mice (two males and two females), subsequently verified as having normal (similar to the C57B6J wild type) retinal histology at 4 months and confirmed that the retinas of their $R 838 S^{+} G C A P 1,2^{+/-}$progeny underwent rapid degeneration after 2 months of age (data not shown). Hence, only the lack of abnormal $\mathrm{Ca}^{2+}$ feedback mediation via GCAPs prevented the CORD6 RetGC1 mutant present in the $R 838 S^{+} G C A P 1,2^{-/-}$rods from triggering the photoreceptor death.

\section{Discussion}

Among the R838 substitutions in RetGC1 linked to the CORD6 (Kelsell et al., 1998; Gregory-Evans et al., 2000; Weigell-Weber et al., 2000; Downes et al., 2001; Payne et al., 2001; Ramamurthy et al., 2001; Kitiratschky et al., 2008; Udar et al., 2003), the R838S mutation, usually present in combinations with other substitutions not directly related to the phenotype, causes one of the most severe forms of GUCY2D CORD6 (Ramamurthy et al., 2001). Expression of R838S RetGC1 in mouse rods (Dizhoor et al., 2016), unlike overexpression of normal RetGC1 (Boye et al., 2013, 2015), results in a rapid decline of rod ERG responses due to progressive degeneration of rod photoreceptors. Notably, photopic ERG responses from cones, which by design of the model do not express the CORD6 cyclase mutant (Fig. 1), remain strong in $R 838 S^{+}$mice, even after the loss of rod ERG (Dizhoor et al., 2016). The clinical symptoms of CORD6 (Kelsell et al., 1998; Gregory-Evans et al., 2000; Hunt et al., 2010) include early onset and decline of vision in childhood due to progressive degeneration of functional photoreceptors. Consistently with that, individual $R 838 S^{+}$rods in the mouse model remain highly functional at the early stage preceding the massive retinal degeneration, albeit with markedly changed shape of photoresponses (Figs. 4-7).

Variability of the photoresponse between different $R 838 S^{+}$ rods (Tables 1,2) likely originates from a nonuniform cell-to-cell transgene expression, and the larger variability in Line 379 would 
be consistent with a larger variation in $R 838 S^{+}$rod outer segment length for this line (Fig. 3). The variability of expression between different rods in these two lines could also explain why, after the initial rapid decline, both rod ERG and rod nuclei count in Line 379 reach a plateau after 3 months of age and then the remaining rods survive for much longer (Dizhoor et al., 2016), while in Line $362 \mathrm{R} 38 \mathrm{~S}^{+}$all rods die out after 3 months of age (Fig. 9).

Photoreceptor degeneration in the CORD6 R838S RetGC1 model resembles the phenotype caused by mutations in GCAP1, which associate with dominant cone and cone -rod degenerations that are clinically distinct from CORD6 (Olshevskaya et al., 2004; Woodruff et al., 2007). Mutations, such as Y99C or E155G, render GCAP1 less sensitive to $\mathrm{Ca}^{2+}$ and hence shift $\mathrm{Ca}^{2+}$ sensitivity of the cyclase in a manner similar to the R838S RetGC1 mutation (Dizhoor et al., 1998; Sokal et al., 1998; Wilkie et al., 2001). Also, similarly to the $\mathrm{R} 838 \mathrm{~S}^{+}$mice, cGMP-gated channel activity and $\mathrm{Ca}^{2+}$ influx in rods expressing mutant GCAP1 increase and the abnormal $\mathrm{Ca}^{2+}$ feedback results in photoreceptor death (Olshevskaya et al., 2004; Woodruff et al., 2007). Nonetheless, the molecular events underlying the pathology are different between the GCAP1 and RetGC1 mutations. While the mutations in GCAP1 directly affect its $\mathrm{Ca}^{2+}$ sensor function by reducing GCAP1 affinity for $\mathrm{Ca}^{2+}$, the $\mathrm{Ca}^{2+}$ sensor properties of GCAPs per se remain unaffected in CORD6. Instead, the R838S mutation in RetGC1 biases its binding to $\mathrm{Mg}^{2+}$-liganded versus $\mathrm{Ca}^{2+}$ liganded GCAP, even in the presence of a larger $\mathrm{Ca}^{2+}$ GCAP pool (Ramamurthy et al., 2001; Peshenko et al., 2004). As a result, the R838S mutant RetGC1 remains in its activated state at higher than normal $\mathrm{Ca}^{2+}$.

The longer time to peak and the increased amplitude of dim flash response (Fig. 6), as well as the more prominent dark noise in the $R_{838 S^{+}}$rods (Fig. 8), all indicate that the dynamic regulation of the cyclase by $\mathrm{Ca}^{2+}$ becomes altered, suppressing its activation in response to the reduction in free $\mathrm{Ca}^{2+}$ after illumination. On the other hand, the increased exchange current in $R_{838 S^{+}}$rods demonstrates more robust efflux of $\mathrm{Ca}^{2+}$ in darkadapted conditions, indicative of higher intracellular $\mathrm{Ca}^{2+}$ concentrations (Iwamoto et al., 2000). However, the increased dark current also suggests that the elevation of $\mathrm{Ca}^{2+}$ levels in these rods does not reach the levels sufficient for complete inhibition of the mutant cyclase in the dark. If the cyclase activity is not fully inhibited in the dark and merely stabilizes a higher RetGC/PDE6 activities equilibrium, then a less cooperative (Fig. $2 A$ ) response of the cyclase to the decrease of free- $\mathrm{Ca}^{2+}$ concentrations could make its light-driven acceleration slower than normal.

Conforming with the hypothesis that the CORD6 mutation of cyclase leads to elevation of free cGMP and $\mathrm{Ca}^{2+}$ in the outer segments (Tucker et al., 1999; Ramamurthy et al., 2001; Peshenko et al., 2004), the abnormalities in $R 838 S^{+}$rod photoresponses can be attributed to the change in $\mathrm{Ca}^{2+}$ sensitivity of the cyclase regulation. Indeed, the larger dark current carried by $\mathrm{Na}^{+}$and $\mathrm{Ca}^{2+}$ through the cGMP-gated channels in $\mathrm{R}^{2} 38 S^{+}$rods indicates elevated free-cGMP concentrations in outer segments (Figs. $4,5)$, consistent with the right shift in the $\mathrm{Ca}^{2+}$ sensitivity of the mutant cyclase and the reduced cooperativity of its $\mathrm{Ca}^{2+}$ dependent deceleration (Fig. 2A). The more prominent exchange current produced by $\mathrm{Ca}^{2+}$ efflux through the NCKX1 (Fig. 7), under the conditions of the experiment limited by the NCKX1 affinity for $\mathrm{Ca}^{2+}$ (Iwamoto et al., 2000), indicates that the free$\mathrm{Ca}^{2+}$ concentration is also increased. Hence, both elevated cGMP and/or $\mathrm{Ca}^{2+}$ in the diseased photoreceptors, both being considered likely apoptotic agents (Olshevskaya et al., 2004; Xu et al., 2013), could trigger the photoreceptor death.
Our results directly demonstrate that the abnormal $\mathrm{Ca}^{2+}$ feedback on the cyclase via GCAPs is the principal initiating event leading to CORD6. $R 838 S^{+}$rods preserved in GCAP-deficient mice further support this evidence (Fig. 9). The dramatic rescue of degeneration in the absence of GCAPs also suggests that processes other than abnormal $\mathrm{Ca}^{2+}$ feedback, such as, for example, potential unfolded protein response directly provoked by the mutant cyclase, are unlikely to create the apoptotic trigger in this case. However, the exact pathway(s) through which the apoptotic progression builds up remains to be established. The elevated free-cGMP content detectable by the increased $R 838 S^{+}$rod photocurrent could conceivably lead to apoptosis via activation of cGMP-dependent protein kinase (PKG or cGK) in photoreceptors (Paquet-Durand et al., 2009; Xu et al., 2013). Both isozymes of the kinase (PKG1 and PKG2, or cGKI and cGKII) are present in photoreceptors (Gamm et al., 2000; Feil et al., 2005). Deletion of a single isozyme, PKG1, does not affect the severity of rod degeneration in the $r d 1$ mouse model, in which cGMP rises due to the lack of PDE6 activity (Wang et al., 2017). However, PKG2 could not be deleted in that study because $r d 1$ and the Prkg2 gene coding for PKG2 are located on the same chromosome. This leaves open a possibility that PKG2 can specifically mediate the apoptotic pathway or does so in a compensatory fashion in the absence of PKG1. Therefore, any future studies of the degeneration mechanism in $\mathrm{R}_{838 S^{+}}$rods will have to address the possible effects of PKG1 and PKG2 individual and double-gene knockouts to delineate or exclude a possible PKG-activated apoptotic pathway in CORD6.

Increase in $\mathrm{Ca}^{2+}$ flux could provide another strong possibility for triggering apoptosis, similar to that in $r d 1$, where deletion of the rod CNG1 channel slows the pace of degeneration (Wang et al., 2017). A larger cGMP-gated current in the outer segments would cause stronger depolarization of $R 838 S^{+}$rods in the dark. Therefore, the increased $\mathrm{Ca}^{2+}$ influx through cGMP-gated channels in the outer segment and/or the voltage-gated $\mathrm{Ca}^{2+}$ channels in the synaptic terminals of the $R 838 S^{+}$rods could overload the $\mathrm{Ca}^{2+}$ scavenging capacity of the mitochondria (Giarmarco et al., 2017) and set the apoptosis in motion. One could also speculate that the increased $\mathrm{Ca}^{2+}$ flux elevates tonic release of glutamate from the synapse in the dark and thus affects the synaptic transmission. However, the early onset of morphological changes and rod degeneration in $R 838 S^{+}$mice reduce scotopic ERG b-waves even at a young age (Dizhoor et al., 2016), making this issue difficult to address. We reason that studies of the degenerative processes in $R 838 S^{+}$rods should help us better understand general mechanisms of CORD6 pathology and, over the long term, could facilitate development of gene therapy approaches to treat the disease.

\section{References}

Arshavsky VY, Burns ME (2012) Photoreceptor signaling: supporting vision across a wide range of light intensities. J Biol Chem 287:1620-1626. CrossRef Medline

Boye SL, Peshenko IV, Huang WC, Min SH, McDoom I, Kay CN, Liu X, Dyka FM, Foster TC, Umino Y, Karan S, Jacobson SG, Baehr W, Dizhoor A, Hauswirth WW, Boye SE (2013) AAV-mediated gene therapy in the guanylate cyclase (RetGC1/RetGC2) double knockout mouse model of leber congenital amaurosis. Hum Gene Ther 24:189-202. CrossRef Medline

Boye SL, Peterson JJ, Choudhury S, Min SH, Ruan Q, McCullough KT, Zhang Z, Olshevskaya EV, Peshenko IV, Hauswirth WW, Ding XQ, Dizhoor AM, Boye SE (2015) Gene therapy fully restores vision to the all-cone $\operatorname{Nrl}(-/-)$ Gucy2e $(-/-)$ mouse model of Leber congenital amaurosis-1. Hum Gene Ther 26:575-592. CrossRef Medline 
Burns ME, Mendez A, Chen J, Baylor DA (2002) Dynamics of cyclic GMP synthesis in retinal rods. Neuron 36:81-91. CrossRef Medline

Dizhoor AM, Lowe DG, Olshevskaya EV, Laura RP, Hurley JB (1994) The human photoreceptor membrane guanylyl cyclase, RetGC, is present in outer segments and is regulated by calcium and a soluble activator. Neuron 12:1345-1352. CrossRef Medline

Dizhoor AM, Olshevskaya EV, Henzel WJ, Wong SC, Stults JT, Ankoudinova I, Hurley JB (1995) Cloning, sequencing, and expression of a $24-\mathrm{kDa}$ $\mathrm{Ca}(2+)$-binding protein activating photoreceptor guanylyl cyclase. J Biol Chem 270:25200-25206. CrossRef Medline

Dizhoor AM, Boikov SG, Olshevskaya EV (1998) Constitutive activation of photoreceptor guanylate cyclase by Y99C mutant of GCAP-1 possible role in causing human autosomal dominant cone degeneration. J Biol Chem 273:17311-17314. CrossRef Medline

Dizhoor AM, Olshevskaya EV, Peshenko IV (2010) $\mathrm{Mg}^{2+} / \mathrm{Ca}^{2+}$ cation binding cycle of guanylyl cyclase activating proteins (GCAPs): role in regulation of photoreceptor guanylyl cyclase. Mol Cell Biochem 334:117124. CrossRef Medline

Dizhoor AM, Olshevskaya EV, Peshenko IV (2016) The R838S mutation in retinal guanylyl cyclase 1 (RetGC1) alters calcium sensitivity of cGMP synthesis in the retina and causes blindness in transgenic mice. J Biol Chem 291:24504-24516. CrossRef Medline

Downes SM, Payne AM, Kelsell RE, Fitzke FW, Holder GE, Hunt DM, Moore AT, Bird AC (2001) Autosomal dominant cone-rod dystrophy with mutations in the guanylate cyclase $2 \mathrm{D}$ gene encoding retinal guanylate cyclase-1. Arch Ophthalmol 119:1667-1673. CrossRef Medline

Feil S, Zimmermann P, Knorn A, Brummer S, Schlossmann J, Hofmann F, Feil R (2005) Distribution of cGMP-dependent protein kinase type I and its isoforms in the mouse brain and retina. Neuroscience 135:863868. CrossRef Medline

Gamm DM, Barthel LK, Raymond PA, Uhler MD (2000) Localization of cGMP-dependent protein kinase isoforms in mouse eye. Invest Ophthalmol Vis Sci 41:2766-2773. Medline

Garcia-Hoyos M, Auz-Alexandre CL, Almoguera B, Cantalapiedra D, Riveiro-Alvarez R, Lopez-Martinez MA, Gimenez A, Blanco-Kelly F, Avila-Fernandez A, Trujillo-Tiebas MJ, Garcia-Sandoval B, Ramos C, Ayuso C (2011) Mutation analysis at codon 838 of the guanylate cyclase 2D gene in Spanish families with autosomal dominant cone, cone-rod, and macular dystrophies. Mol Vis 17:1103-1109. Medline

Giarmarco MM, Cleghorn WM, Sloat SR, Hurley JB, Brockerhoff SE (2017) Mitochondria maintain distinct $\mathrm{Ca}^{2+}$ pools in cone photoreceptors. J Neurosci 37:2061-2072. CrossRef Medline

Gregory-Evans K, Kelsell RE, Gregory-Evans CY, Downes SM, Fitzke FW, Holder GE, Simunovic M, Mollon JD, Taylor R, Hunt DM, Bird AC, Moore AT (2000) Autosomal dominant cone rod retinal dystrophy (CORD6) from heterozygous mutation of GUCY2D, which encodes retinal guanylate cyclase. Ophthalmology 107:55-61. CrossRef Medline

Howes K, Bronson JD, Dang YL, Li N, Zhang K, Ruiz C, Helekar B, Lee M, Subbaraya I, Kolb H, Chen J, Baehr W (1998) Gene array and expression of mouse retina guanylate cyclase activating proteins 1 and 2 invest. Invest Ophthalmol Vis Sci 39:867-875. Medline

Hunt DM, Buch P, Michaelides M (2010) Guanylate cyclases and associated activator proteins in retinal disease. Mol Cell Biochem 334:157-168. CrossRef Medline

Imanishi Y, Yang L, Sokal I, Filipek S, Palczewski K, Baehr W (2004) Diversity of guanylate cyclase-activating proteins (GCAPs) in teleost fish: characterization of three novel GCAPs (GCAP4, GCAP5, GCAP7) from zebrafish (Danio rerio) and prediction of eight GCAPs (GCAP1-8) in pufferfish (Fugu rubripes). J Mol Evol 59:204-217. CrossRef Medline

Ito S, Nakamura M, Ohnishi Y, Miyake Y (2004) Autosomal dominant cone-rod dystrophy with R838H and R838C mutations in the GUCY2D gene in Japanese patients. Jpn J Ophthalmol 48:228-235. CrossRef Medline

Iwamoto T, Uehara A, Imanaga I, Shigekawa M (2000) $\mathrm{The}^{+} / \mathrm{Ca}^{2+}$ exchanger NCX1 has oppositely oriented reentrant loop domains that contain conserved aspartic acids whose mutation alters its apparent $\mathrm{Ca}^{2+}$ affinity. J Biol Chem 275:38571-38580. CrossRef Medline

Jacobson SG, Cideciyan AV, Peshenko IV, Sumaroka A, Olshevskaya EV, Cao L, Schwartz SB, Roman AJ, Olivares MB, Sadigh S, Yau KW, Heon E, Stone EM, Dizhoor AM (2013) Determining consequences of retinal membrane guanylyl cyclase (RetGC1) deficiency in human Leber congenital amaurosis en route to therapy: residual cone-photoreceptor vision correlates with biochemical properties of the mutants. Hum Mol Genet 22:168-183. CrossRef Medline

Kelsell RE, Gregory-Evans K, Payne AM, Perrault I, Kaplan J, Yang RB, Garbers DL, Bird AC, Moore AT, Hunt DM (1998) Mutations in the retinal guanylate cyclase (RETGC-1) gene in dominant cone-rod dystrophy. Hum Mol Genet 7:1179-1184. CrossRef Medline

Kitiratschky VB, Wilke R, Renner AB, Kellner U, Vadalà M, Birch DG, Wissinger B, Zrenner E, Kohl S (2008) Mutation analysis identifies GUCY2D as the major gene responsible for autosomal dominant progressive cone degeneration. Invest Ophthalmol Vis Sci 49:5015-5023. CrossRef Medline

Koch KW, Dell'Orco D (2015) Protein and signaling networks in vertebrate photoreceptor cells. Front Mol Neurosci 8:67. CrossRef Medline

Koch KW, Stryer L (1988) Highly cooperative feedback control of retinal guanylate cyclase by calcium ions. Nature 334:64-66. CrossRef Medline

Krispel CM, Chen D, Melling N, Chen YJ, Martemyanov KA, Quillinan N, Arshavsky VY, Wensel TG, Chen CK, Burns ME (2006) RGS expression rate-limits recovery of rod photoresponses. Neuron 51:409-416. CrossRef Medline

Laura RP, Dizhoor AM, Hurley JB (1996) The membrane guanylyl cyclase, retinal guanylyl cyclase-1, is activated through its intracellular domain. J Biol Chem 271:11646-11651. CrossRef Medline

Lowe DG, Dizhoor AM, Liu K, Gu Q, Spencer M, Laura R, Lu L, Hurley JB (1995) Cloning and expression of a second photoreceptor-specific membrane retina guanylyl cyclase (RetGC), RetGC-2. Proc Natl Acad Sci U S A 92:5535-5539. CrossRef Medline

Makino CL, Peshenko IV, Wen XH, Olshevskaya EV, Barrett R, Dizhoor AM (2008) A role for GCAP2 in regulating the photoresponse guanylyl cyclase activation and rod electrophysiology in GUCA1B knock-out mice. J Biol Chem 283:29135-29143. CrossRef Medline

Makino CL, Wen XH, Olshevskaya EV, Peshenko IV, Savchenko AB, Dizhoor AM (2012) Enzymatic relay mechanism stimulates cyclic GMP synthesis in rod photoresponse: biochemical and physiological study in guanylyl cyclase activating protein 1 knockout mice. PLoS One 7:e47637. CrossRef Medline

Mendez A, Burns ME, Sokal I, Dizhoor AM, Baehr W, Palczewski K, Baylor DA, Chen J (2001) Role of guanylate cyclase-activating proteins (GCAPs) in setting the flash sensitivity of rod photoreceptors. Proc Natl Acad Sci U S A 98:9948-9953. CrossRef Medline

Olshevskaya EV, Calvert PD, Woodruff ML, Peshenko IV, Savchenko AB, Makino CL, Ho YS, Fain GL, Dizhoor AM (2004) The Y99C mutation in guanylyl cyclase-activating protein 1 increases intracellular $\mathrm{Ca}^{2+}$ and causes photoreceptor degeneration in transgenic mice. J Neurosci 24:6078-6085. CrossRef Medline

Olshevskaya EV, Peshenko IV, Savchenko AB, Dizhoor AM (2012) Retinal guanylyl cyclase isozyme 1 is the preferential in vivo target for constitutively active GCAP1 mutants causing congenital degeneration of photoreceptors. J Neurosci 32:7208-7217. CrossRef Medline

Palczewski K, Subbaraya I, Gorczyca WA, Helekar BS, Ruiz CC, Ohguro H, Huang J, Zhao X, Crabb JW, Johnson RS (1994) Molecular cloning and characterization of retinal photoreceptor guanylyl cyclase-activating protein. Neuron 13:395-404. CrossRef Medline

Paquet-Durand F, Hauck SM, van Veen T, Ueffing M, Ekström P (2009) PKG activity causes photoreceptor cell death in two retinitis pigmentosa models. J Neurochem 108:796-810. CrossRef Medline

Payne AM, Morris AG, Downes SM, Johnson S, Bird AC, Moore AT, Bhattacharya SS, Hunt DM (2001) Clustering and, frequency of mutations in the retinal guanylate cyclase (GUCY2D) gene in patients with dominant cone-rod dystrophies. J Med Genet 38:611-614. CrossRef Medline

Perrault I, Rozet JM, Gerber S, Ghazi I, Ducroq D, Souied E, Leowski C, Bonnemaison M, Dufier JL, Munnich A, Kaplan J (2000) Spectrum of retGC1 mutations in Leber's congenital amaurosis. Eur J Hum Genet 8:578-582. CrossRef Medline

Peshenko IV, Dizhoor AM (2004) Guanylyl cyclase-activating proteins (GCAPs) are $\mathrm{Ca}^{2+} / \mathrm{Mg}^{2+}$ sensors: implications for photoreceptor guanylyl cyclase (RetGC) regulation in mammalian photoreceptors. J Biol Chem 279:16903-16906. CrossRef Medline

Peshenko IV, Dizhoor AM (2006) $\mathrm{Ca}^{2+}$ and $\mathrm{Mg}^{2+}$ binding properties of GCAP-1 evidence that $\mathrm{Mg}^{2+}$-bound form is the physiological activator of photoreceptor guanylyl cyclase. J Biol Chem 281:23830-23841. CrossRef Medline

Peshenko IV, Moiseyev GP, Olshevskaya EV, Dizhoor AM (2004) Factors 
that determine $\mathrm{Ca}^{2+}$ sensitivity of photoreceptor guanylyl cyclase kinetic analysis of the interaction between the $\mathrm{Ca}^{2+}$-bound and the $\mathrm{Ca}^{2+}$-free guanylyl cyclase activating proteins (GCAPs) and recombinant photoreceptor guanylyl cyclase 1 (RetGC-1). Biochemistry 43:13796-13804. CrossRef Medline

Peshenko IV, Olshevskaya EV, Savchenko AB, Karan S, Palczewski K, Baehr W, Dizhoor AM (2011) Enzymatic properties and regulation of the native isozymes of retinal membrane guanylyl cyclase (RetGC) from mouse photoreceptors. Biochemistry 50:5590-5600. CrossRef Medline

Peshenko IV, Olshevskaya EV, Dizhoor AM (2015a) Evaluating the role of retinal membrane guanylyl cyclase 1 (RetGC1) domains in binding guanylyl cyclase-activating proteins (GCAPs). J Biol Chem 290:6913-6924. CrossRef Medline

Peshenko IV, Olshevskaya EV, Dizhoor AM (2015b) Dimerization domain of retinal membrane guanylyl cyclase 1 (RetGC1) is an essential part of guanylyl cyclase-activating protein (GCAP) binding interface. J Biol Chem 290:19584-19596. CrossRef Medline

Peshenko IV, Olshevskaya EV, Dizhoor AM (2016) Functional Study and Mapping Sites for Interaction with the Target Enzyme in Retinal Degeneration 3 (RD3) Protein. J Biol Chem 37:19713-19723. CrossRef Medline

Pugh EN Jr, Nikonov S, Lamb TD (1999) Molecular mechanisms of vertebrate photoreceptor light adaptation. Curr Opin Neurobiol 9:410-418. CrossRef Medline

Ramamurthy V, Tucker C, Wilkie SE, Daggett V, Hunt DM, Hurley JB (2001) Interactions within the coiled-coil domain of RetGC-1 guanylyl cyclase are optimized for regulation rather than for high affinity. J Biol Chem 276:26218-26229. CrossRef Medline

Reiländer H, Achilles A, Friedel U, Maul G, Lottspeich F, Cook NJ (1992) Primary structure and functional expression of the $\mathrm{Na} / \mathrm{Ca}$, K-exchanger from bovine rod photoreceptors. EMBO J 11:1689-1695. Medline

Sokal I, Li N, Surgucheva I, Warren MJ, Payne AM, Bhattacharya SS, Baehr W, Palczewski K (1998) GCAP1 (Y99C) mutant is constitutively active in autosomal dominant cone dystrophy. Mol Cell 2:129-133. CrossRef Medline

Stone EM (2007) Leber congenital amaurosis-a model for efficient genetic testing of heterogeneous disorders: LXIV Edward Jackson memorial lecture. Am J Ophthalmol 144:791-811. CrossRef Medline

Tucker CL, Woodcock SC, Kelsell RE, Ramamurthy V, Hunt DM, Hurley JB (1999) Biochemical analysis of a dimerization domain mutation in RetGC-1 associated with dominant cone-rod dystrophy. Proc Natl Acad Sci U S A 96:9039-9044. CrossRef Medline

Udar N, Yelchits S, Chalukya M, Yellore V, Nusinowitz S, Silva-Garcia R, Vrabec T, Hussles Maumenee I, Donoso L, Small KW (2003) Identifica- tion of GUCY2D gene mutations in CORD5 families and evidence of incomplete penetrance. Hum Mutat 21:170-171. CrossRef Medline

Wang JS, Nymark S, Frederiksen R, Estevez ME, Shen SQ, Corbo JC, Cornwall MC, Kefalov VJ (2014) Chromophore supply rate-limits mammalian photoreceptor dark adaptation. J Neurosci 34:11212-11221. CrossRef Medline

Wang T, Tsang SH, Chen J (2017) Two pathways of rod photoreceptor cell death induced by elevated cGMP. Hum Mol Genet 26:2299-2306. CrossRef Medline

Weigell-Weber M, Fokstuen S, Török B, Niemeyer G, Schinzel A, Hergersberg M (2000) Codons 837 and 838 in the retinal guanylate cyclase gene on chromosome 17p: hot spots for mutations in autosomal dominant conerod dystrophy? Arch Ophthalmol 118:300. CrossRef Medline

Wilkie SE, Li Y, Deery EC, Newbold RJ, Garibaldi D, Bateman JB, Zhang H, Lin W, Zack DJ, Bhattacharya SS, Warren MJ, Hunt DM, Zhang K (2001) Identification and functional consequences of a new mutation (E155G) in the gene for GCAP1 that causes autosomal dominant cone dystrophy. Am J Hum Genet 69:471-480. CrossRef Medline

Woodruff ML, Sampath AP, Matthews HR, Krasnoperova NV, Lem J, Fain GL (2002) Measurement of cytoplasmic calcium concentration in the rods of wild-type and transducin knock-out mice. J Physiol 542:843-854. CrossRef Medline

Woodruff ML, Olshevskaya EV, Savchenko AB, Peshenko IV, Barrett R, Bush RA, Sieving PA, Fain GL, Dizhoor AM (2007) Constitutive excitation by Gly90Asp rhodopsin rescues rods from degeneration caused by elevated production of cGMP in the dark. J Neurosci 27:8805-8815. CrossRef Medline

Xu J, Morris L, Thapa A, Ma H, Michalakis S, Biel M, Baehr W, Peshenko IV, Dizhoor AM, Ding XQ (2013) cGMP accumulation causes photoreceptor degeneration in CNG channel deficiency: evidence of cGMP cytotoxicity independently of enhanced CNG channel function. J Neurosci 33: 14939-14948. CrossRef Medline

Yang RB, Foster DC, Garbers DL, Fülle HJ (1995) Two membrane forms of guanylyl cyclase found in the eye. Proc Natl Acad Sci U S A 92:602-606. CrossRef Medline

Yang RB, Robinson SW, Xiong WH, Yau KW, Birch DG, Garbers DL (1999) Disruption of a retinal guanylyl cyclase gene leads to cone-specific dystrophy and paradoxical rod behavior. J Neurosci 19:5889-5897. Medline

Yau KW, Hardie RC (2009) Phototransduction motifs and variations. Cell 139:246-264. CrossRef Medline

Yau KW, Nakatani K (1984) Electrogenic Na-Ca exchange in retinal rod outer segment. Nature 311:661-663. CrossRef Medline 